\title{
Islam and Civilization: Islam as Source of Value for Human Life
}

\author{
Afiful Ikhwan ${ }^{1}$, Faruuq Tri Fauzi ${ }^{2}$ \\ Universitas Muhammadiyah Ponorogo, Indonesia ${ }^{1}$ \\ Sekolah Tinggi Agama Islam Muhammadiyah Tulungagung, Indonesia ${ }^{2}$ \\ \{afifulikhwan@umpo.ac.id $\left.{ }^{1}\right\}$
}

\begin{abstract}
The relationships among man, neighbors and universe can't do neutral or apathetic attitude. Trends for sympathy, anti-starch or neutrality itself is an attitude. And every position has a consequence of an assessment, whether the judgment is based on the principle of rational objective or emotional subjective. In the line of inquiry from understanding, sympathy, admiration, respect, worship, love, or otherwise, misunderstanding, anti-starvation, disgust, humiliation, hate, even neutrality is manifestations and embodiments of judgment. In this text will be discussed in more detail the problem of how the value system in human life or community. Good or bad in a human being is created by man himself (community group).
\end{abstract}

Keywords: Islam, Civilization, Values, and Humans.

\section{Introduction}

Human as social beings always lives together in the sense that human lives in the interaction and interdependency of each other. Human needs each other both physically and spiritually. In the process of communication is required values, norms, and rules, because it determines the boundaries of behavior in public life. Therefore, social relationships in society are entirely the value because there are no values without any social relations. The rules of life are not always manifested in real, but there is an incentive in humans to do or not to do certain things. It is abstract but can be beneficial.

In society, as a human Gemeinschaft live together, man as a person, with unique individuality traits mingling with each other. Sometimes mutual understanding, sympathy, mutual respect, and love. But there is the human nature of anti-starch, misunderstanding, hate, betrayal and so on. They are the forms of human behavior about the prevailing values. Every relationship between humans is always accompanied by the assessment process, both active and passive, both on the relationship of each other and with the environment of the universe[1] The assessment process is done consciously or unconsciously. Such a reality is a tendency and a human nature. 


\section{Result and discussion}

\subsection{Understanding Values in Life}

Tylor in Imran Manan suggests morals including parts of culture, the standards of good and evil, right and wrong, all of which is a broader concept belong to 'value.' This is seen from the aspect of instructional delivery which is said that education includes the distribution of knowledge, skills, and values [2].

The position of value in every culture is critical, the understanding of the cultural value system and the orientation of cultural values are fundamental in the context of understanding the behavior of a society and the educational system used to convey the order of action and cultural products that are imbued by the value system of the community concerned. The author defines value as a conception, explicit or implicit, a unique feature of a person or group of people, about the things desired which influence the selection of the various means, tools, purposes of deed available. The orientation of cultural values is an organized general conception, which affects behavior related to nature, social positions in life, people's relationships with people and about desirable and undesirable things that may be related to relationships between people and the environment and fellow human beings.

This cultural value system is a series of abstract concepts that live in society, about what is considered relevant and valuable, but also about what is deemed to be trivial and worthless in life. This cultural value system serves as a guide and a driver of human behavior in life that concretely manifests itself. From the aesthetic value system including norms and attitudes in the abstract form is reflected in the way of thinking and the form of concrete seen in the form of behavior patterns of members of a society [3].

According to the view of Sutan Takdir Alisyahbana (STA) called culture is the embodiment of values. An important part is to make a classification of the universal values that exist in human society. He felt that the rating of values used by E. Spranger is the best to be used in viewing the culture of humanity. Spranger pointed out six fundamental values in every culture [4]:

- The amount of the theory that determines the identity of something.

- Economic value in the form of utility or usefulness.

- Religious values in the form of Heilige or holiness.

- The value of art that embodies expressiveness or expression.

- The value of power or politics.

- The value of solidarity that incarnates in love, friendship, cooperation and others.

These six values each have their logic, goals, norms, and reality. According to the STA, the dominant costs that function to organize the community organization are the value of power and the value of solidarity. In human life, it is judged or will do something because of cost. The amount of where to go depends on the level of understanding of the value.

\subsection{Types and Functions of Values in Human Life}

Prof. Notonegoro distinguishes the value into three kinds, namely: (1) The amount of material, which includes various conceptions about everything that is useful for the human body, (2) Vital value, which provides for multiple understandings related to everything that is useful for humans in carrying out various activity, and (3) spiritual value, which includes various conceptions related to everything related to the spiritual needs of man: the value of truth, that is derived from human reason (creativity), the amount of beauty, which is derived 
from the element of feeling (aesthetic), the moral value, which is obtained from the part of will (karsa), and religious value (religiosity), the amount that comes from revelation (revelation) from God[5].

\subsubsection{Individual value - social value}

An individual may have different values, even contrary to other individuals in his society. The amount held by a unique and different from the value held by most members of the community can be called individual value. While the values adopted by most members of society are called social values.

\subsubsection{Characteristics of social value}

- Social value is an abstract construction in the minds of people created through social interaction,

- Social benefits are not innate, but learned through the process of socialization, made private by internalization and will affect the actions of adherents in everyday life is realized or without realizing it (enculturation),

- Social value gives satisfaction to its supporters,

- Social benefits are relative,

- Social value relates to each other to form a value system,

- The value system varies from one culture to another,

- Each value has different effects on individuals or groups,

- Social value involves emotional and psychological elements, and

- Social value affects personal development.

\subsubsection{Social Values can work}

- As a driving factor, it relates to values that are related to ideas or expectations,

- As guidance on how to think and act, guide choices, means to weigh social rewards, gather people in a social unit,

- As a bastion of protection or maintaining cultural stability.

2.2.4 The relation of value with the norm in human life (community) seen from the level of sanctions or binding strength there are:

- Procedures (usage). Procedures (usage); is the norm with penalties that are very ringat against violators, for example, the rule of holding a fork or spoon when eating, how to hold a glass when drinking. Violation of this norm is only declared rude.

- Habit (Folkways). Folkways; is a way of acting that is favored by society, so it is done repeatedly by many people. For example, say a greeting when met, bowing as a tribute to an older person, etc.

- Practice (mores). Code of conduct is a norm that comes from philosophy, religious teachings or ideology adopted by society. The offense is called evil. Examples: prohibition of adultery, gambling, drinking alcohol, drug use, stealing, and so on.

- Customs. Adat is an unwritten norm but solid binding when custom becomes written it becomes customary law. 
- Law (law). Law is the norm in the form of written rules, the provisions of sanctions against anyone who violates formulated explicitly. In contrast to other models, the implementation of legal standards is supported by the apparatus, thus enabling strict enforcement [6][7].

Four broad types of values can be distinguished within Schwartz's circumplex model: (a) Self-transcendence, which includes universalism (i.e., understanding, appreciation, tolerance, and protection for the welfare of all people and nature) and benevolence (i.e., preservation and enhancement of the health of acquaintances and loved ones); (b) conservation, which includes tradition (i.e., commitment and acceptance of the ideas that traditional culture or religion provides), conformity (i.e., restraint of impulses likely to harm others and violate social expectations), and security (i.e., harmony and stability of society, of relationships, and of self); (c) self-enhancement, which refers to values of power and achievement; and (d) openness to change, which refers to values of self-direction, stimulation, and hedonism [8].

The relationship between values and social norms in a continually evolving society, values are constantly changing. Shifting costs in many ways will also affect the habits or behavior that prevail in society. In rural areas, since the broadcasts and impressions of private telecommunications began to be known, it was slowly visible that in the community started to happen a shift in values, such as about modesty. Impressions dominated by cutting-edge soap operas that often show relatively well-dressed artists, have more or less caused the limits of society's tolerance to become looser. Various circles are increasingly permissive towards teenagers who initially dressed usually, became involved in skimpy minimal clothing and seemed bolder. The extended blackish-haired model that used to be the pride of the village girls may now have been considered a symbol of backwardness. Instead, which is now considered trendy and in keeping with the contemporary context (modern) is a short blond hairstyle. So the change in value will affect the norms prevailing in society.

\subsection{The Emergence of Value Systems in Human Life}

Value arises from the agreement within a people; primitives have value agreements on which the ethical basis to know something is good or bad. And in a modern society, every action will refer to the mutually agreed consent in a deliberative assembly which its representatives struggle in a parliament, resulting in the positive law of judgment and judgment of things whether or not it may be.

Narcotics, before being agreed as a forbidden good, is the object of the nobility and the caravans, meaning it has no legal value (permissible) when it is unknown of its merits and harm so that the wearer is lawful (halal) and the action is not said wrong (guilty). But after we agree that the narcotics are harmful and according to positive law is prohibited the user's behavior is a vice, even said to be a crime to be fought.

So the conclusion is that every action can be said good or bad if the act is in the foundation of the ethical value of something. For a person does not have a basis in his actions then that person can be categorized into six go logan mentioned in a hadith, namely: (mafhum mukhabarat) ie the person whose activities are exempt from legal liability are 1) small child (shabby) to baligh (Whitlam), 2 ) people sleep (name) to wake up (istiqadh), 3) crazy (majnun) to conscious (Zulfiqar) [HR. Bukhari]; 4) people who forget (nisyan), 5) the guilty (that '), and 6) the people who are forced (much) [HR. Ibn Majah [9].

Several favorite foundations are used in the world community, among others: Divine ethics (religion, Islam, Christianity, Hinduism, Buddhism, Catholic, etc.), cultural ethics (ethics Java, Sunda, Malay, adat, etc.) Philosophy (Greek, Tao, communist, Pancasila, etc.), primitive 
culture, etc. In Islam, the meaning of meaning is that man understands what is right and wrong and he can distinguish between them and then practice them. The notion of good and evil is not traversed by experience, but has existed since the first spirit was breathed."By the soul and its consummation, God inspires the soul (the path) of ugliness and goodness" (Surah AsShams [91]: 7-8)[10].

Understanding (understanding) good and evil is a basic human that must be revealed more clearly, on what basis we do something practice. Imam Al-Ghazali calls the a priori sense as the qawwali term. From what these meanings are obtained, as he puts it: "The mind becomes healthy and balances back and safely and confidently it can reclaim all the earliest notions of reason. All this happens not by arranging excuses or composing information, but with the nur (light) emitted by God Almighty, into the mind of the ma'rifat" [11].

Here, Al-Ghazaly restores it to the basic sense of qawwali which is the divine notion, while Plato calls it the "idea." He reveals that the "idea" essentially already exists, human life searching for it by way of contemplation or for artists commonly called for inspiration. Clearly, "idea" does not arise from the experience or the creation of the mind to produce an idea.

And these ideas are pure, do not contain good or bad and are universal before they come down to a real legal agreement. For example, a person who gets the idea of illustrating the curve of a human body is purely an opinion, no good or bad value in the concept, except that there is an agreement that the image contains an evil influence in a particular society, but on the contrary it is something which is good if in association with the study of medical science in revealing the facts in the anatomy.

For that reason, one of the paths of religion determines the limits of value so that humans become easy in determining the attitude in law and personal responsibility and the rights of others in every action. For if there is no principle of value in fear, everything will become unclear and make humans act at will without any value action. If this happens then, man will behave brutally and apply the law of the jungle or become a colonist and slavery.

This has happened in colonial times around the world, where the colonizers think that human beings no longer have any value so that they make the slave as slaves traded in the market, like animals. Likewise, the lands that lie regarded as no master, where they stand there is hers.

\subsection{Relationship of Values and Norms in Human Life}

The judgment of all things is driven by the internal factors that are already human potential and saturation. But how to judge truth, objectively is a matter of norms, normative principles. Truth, kindness, virtue, honesty, love of others, and so forth are the potential of human dignity. It is social idealism to realize the potential of human dignity. Man's goodness is measured by the fact of how far he understands the possibility of human dignity in his behavior. Human dignity and personality are always regulated by prevailing norms in terms of the extent to which people are loyal to the current values. Thus the values and standards will shape the human personality. Man does not mean anything without the values, norms that apply.

The judgment of all things is driven by the internal factors that are already human potential and saturation. But how to judge truth objectively is a matter of norms, normative principles. Truth, kindness, virtue, honesty, love of others, and so forth are the potential of human dignity. It is social idealism to realize the potential of human dignity. Man's goodness is measured by the fact of how far he understands the possibility of human dignity in his behavior. Human dignity and personality are always regulated by prevailing norms in terms of the extent to 
which people are loyal to the current values. Thus the values and standards will shape the human personality. Man does not mean anything without the values, norms that apply.

\subsubsection{Social Value:}

- Constituting community constructions created through the interaction between members,

- Helping the community to function correctly,

- Learned or not innate,

- Affect emotions,

- Influence personal development in society, both positively and negatively, etc.

The functions of value include:

- As a set of tools ready to set personal and group self-esteem,

- Encouraging, leading, and sometimes pressuring people to do good,

- As a tool of solidarity among members of the community group,

- As for direction in thinking and behaving ideally in society and,

- Becoming the ultimate goal for human beings in fulfilling their social roles.

\subsubsection{Social Norms}

The rules or conditions that bind the citizens of the group in society, used as a blend, the order, and the control of the appropriate and acceptable behavior together. Robert M.Z Lawang divides the norm into two kinds, namely customs (mores) and habits (folkway). Rules in society have different binding forces, some are weak, and some are strong. Based on the strength of binding norms can be divided as follows:

- Method (Usage); is a norm that refers to a form of a deed and has a feeble strength compared with the habit.

- Habit (Folkways); is a norm that has higher power than the means (usage) and is a repetitive act in the same form so that it can be said that people liked the action. Habit is a behavior accepted by society.

- Practice (Mores); is a norm that develops from the habit, where the pattern is not merely regarded as a way of behaving alone, but even accepted as regulatory norms.

- Customs (Custom); is an eternal code of conduct as well as strongly integrated with patterns of community behavior. Community members who violate it will suffer severe sanctions that are sometimes received indirectly.

Based on its fields the norm is divided as follows:

- Norms Religion, is a norm containing rules that are compatible with the religion and beliefs held by a person or society.

- The norm of Courtesy is the norm that governs a person is behaving in social life.

- Norms of Habits constitutes the rule of a person or group in performing an activity based on tradition or behavior that is repeated in the same form to become a habit.

- Moral Norms is one of the rules that derive from morals or their conscience about what is right and what is wrong.

- Law Norms, constituting the most strict rule of law of sanctions and laws consisting of written law (KUHP, Constitution, PP) and unwritten law such as adat law [12]. 
A person's value affects his behavior. While the norms regulate human behavior associated with the value contained in a group, that is, to keep the cost of the group to survive, then devised standards to guard it. Therefore, a violation of the norm also means a violation of the value held by the group or society.

\subsection{The Importance of Values and Norms in Human Life}

A norm is created to create order in society. For this reason, each model has two kinds of content, namely as follows.

- It contains a command, a necessity for someone to do something or not to do something because it is viewed as a result-Norms and Laws and the consequences will have a good effect. For example, a child must respect his parents.

- Contains a prohibition, which is a precaution to do or the Law does not do something because it is seen that the consequences will be severe. For example, smoking bans in public places. Do you know about the various norms prevailing in society? In the life of the community, there are four kinds of rules, namely standards of decency, norms of decency, religious norms, and legal norms [13].

According to Soo Jiuan Tan, from the results of his research in 2001-2011, the influence of value on the welfare of society in Singapore is increasing due to the higher society education from year to year [14], this is by the word of Allah SWT which means: "... Allah will lift (degree) of those who believe among you and those who are given knowledge of some degree ... " (Surat al-Mujadalah [58]: 11)[10].

\section{Conclusion}

Value action is the most important right to determine something good or bad. If this is clear then we will be able to say my actions are wrong or my deeds are right, then sin me if so and pamper my actions if so. Islam emphasizes every effort must be based on the intention of lillahita'ala (because Allah ta'ala) to distinguish ethical acts other than Allah, so that if not based on purpose because of Allah, then his actions are not accepted by Allah SWT.

Values are divided into three kinds, namely: (1) Material value, (2) Vital value, and (3) Spiritual value. Characteristics of social value: Social value is an abstract construction in the minds of people created through social interaction, Social value is not innate, Social value gives satisfaction to its adherents, Social value is relative, Social value relates to each other to form a value system, System values vary from one culture to another, Each value has a different effect on individuals or groups, Social value involves emotional and psychological elements, and Social value affects personal development. Social Value can function: As a driving factor, As a direction on how to think and act, As a bastion of protection or maintain cultural stability.

Social values have characteristics such as a) constituting community constructions created through the interaction between members, b) helping the community to function correctly, c) learned or not innate, d) can affect emotions, e) can affect personal development in society, both positively and negatively, etc. Norms are part of the culture; Norma grew out of a social process. Patterns are divided into four kinds, namely customs (mores) habits (folkway), ways (Usage), behavior (Mores). More specifically: Religious norms, norms of decency, customs, standards of morality and legal rules. 


\section{References}

[1] A. Ikhwan, Filsafat Pendidikan Islam: Memahami Prinsip Dasar. Yogyakarta: Diandra Kreatif, 2018.

[2] I. Manan, Pendidikan adalah enkulturasi. Jakarta, 1989.

[3] M. Asih and P. Usman, Teori-Teori Sosial Budaya. Jakarta: Dirjen Dikti Depdikbud, 1994.

[4] A. K. Mihardja and Sutan Takdir Alisjahbana, Polemik Kebudayaan. Jakarta: Pustaka Jaya, 1986.

[5] M. Suriadi Samsuri, Mursidin, "Character Education Based on Gender Justice in The Islamic Perspective," Al-Hayat J. Islam. Educ., vol. 2, no. 2, pp. 202-212, 2018.

[6] Bryan Tobing, "Nilai dan Norma Sosial," Bryan Tobing Blog, 2012. .

[7] F. I. Febriansyah, "Impact of Ratification of Government Regulations Substituting Law Number 2 of 2017 Becomes Act on Society in Running Activities of Islamic Community Organizations in Indonesia," Al-Hayat J. Islam. Educ., vol. 2, no. 2, pp. 193-201, 2018.

[8] K. C. Zhang, C. H. Hui, J. Lam, E. Y. Y. Lau, S. Cheung, and D. S. Y. Mok, "Personal Spiritual Values and Quality of Life: Evidence from Chinese College Students," J. Relig. Health, vol. 53, no. 4, pp. 986-1002, Aug. 2014.

[9] A. Imran, Disertasi : Kontribusi Hukum Islam Terhadap Pembangunan Hukum Nasional (Studi Tentang Konsepsi Taklif dan Mas`uliyyat dalam Legislasi Hukum). Semarang: Universitas Diponegoro, 2008.

[10] A. Ikhwan, "TEORI DASAR METODE STUDI ISLAM (Pembacaan atas Pemikiran Charles J. Adams dan Richard C. Martin)," At-Tasyrih J. Pendidik. Islam, vol. 1, no. 1, 2015.

[11] A. Ikhwan, "Penerapan Manajemen Hubungan Sekolah dan Masyarakat dalam Perspektif Islam," Al-Hayat J. Islam. Educ., vol. 2, no. 1, p. 1, 2018.

[12] A. Ikhwan, "Development Of Quality Management Islamic Education In Islamic Boarding School (Case Study Madrasah Aliyah Ash Sholihin)," Al-Hayat J. Islam. Educ., vol. 1, no. 1, p. 117, 2017.

[13] Departemen Agama, Al-Qur'an dan Terjemahnya. Jakarta: Depag R.I, 1999.

[14] S. Sangkan, "Etika Islam," Media Isnet, 1999. 